\title{
Biologic Fixation of the Electrode Cable of Cochlea Implants
}

\author{
Karl-Bernd Hüttenbrink Thomas Zahnert Uwe Vogel Gert Hofmann
}

Department of Oto-Rhino-Laryngology, Technical University Dresden, Germany

\section{Key Words}

Cochlea implants · Electrode cable · Fixation · Adhesive · Experiments

\begin{abstract}
Objectives: To verify the necessity for special surgical techniques or clips for fixation of the electrode cable of a cochlea implant against dislocation, and to test the stability of postoperative biologic cicatrization as the sole and solid anchoring of the cable. Material: Temporal bone experiments with a simulated connective tissue sheath around conventional (Med El Combi $40+$ ) and prototype (profiled surface) electrode cables. Results and Conclusions: The electrode cable is anchored securely in a sheath of scar tissue, since unphysiologic loads are needed for pulling it out of its anchorage. The drag during one extraction trial with a profiled cable even resulted in the rupture of the cable. These results confirm our confidence in this biologic fixation of the electrode cable inside its postoperative cicatric tissue sheath. More than 80 cochlea implantations with the electrode simply imbedded in a drop of fibrin glue in the posterior tympanotomy never demonstrated a shift of the electrodes in the last 8 years. Therefore, special fixation of the electrode cable with clips or surgical techniques is not necessary.
\end{abstract}

Copyright $@ 2001$ S. Karger AG, Basel

\section{Biologische Befestigung des Elektrodenkabels eines Kochlearimplantats}

Fragestellung: Muss das Elektrodenkabel eines Kochlearimplantats durch spezielle operative Techniken oder Halterungen gegen ein Herausrutschen aus der Kochlea gesichert werden, oder genügt die Einscheidung in dem postoperativ sich ausbildenden Narbengewebe für eine ausreichend stabile Fixierung? Material: Felsenbeinexperimente mit einer Simulation der narbigen Einbettung konventioneller und modifizierter (geriffelter Oberfläche) Elektrodenkabel eines Kochlearimplantats (Med El Combi 40+). Ergebnisse und Schlussfolgerungen: Ein Herausziehen eines in simuliertem Narbengewebe eingescheideten Elektrodenkabels gelang erst bei erheblichen, unphysiologischen Kräften; eine Rifflung der Oberfläche des Silikon- kabels erhöhte den Reibungswiderstand über die Reissfestigkeit des Kabels. Das Vertrauen in die biologische Fixierung des Elektrodenkabels durch die Verankerung im Narbengewebe ist somit gerechtfertigt, und wird auch durch unsere klinische Erfahrung bestätigt: in über 80 Operationen, bei denen das Kabel des Kochlearimplantats nur durch Einbettung in Fibrinkleber am Rahmen der posterioren Tympanotomie gesichert worden war, liess sich in den letzten 8 Jahren in keinem Fall eine Elektrodenverlagerung nachweisen. Eine gezielte Fixation des Elektrodenkabels durch künstliche Halterungen oder spezielle OP-Techniken erscheint somit nicht erforderlich.

\section{Fixation biologique du câble-électrode de l'implant cochléaire}

Problématique: Afin d'éviter tout glissement de l'électrode de l'implant cochléaire, est-il préférable d'en assurer la fixation par une technique opératoire particulière ou bien est-il suffisant de gainer l'électrode dans les tissus cicatriciels qui se forment après l'opération? Méthode: Nous avons procédé à des expériences sur le rocher en simulant une inclusion cicatricielle d'un câble-électrode classique (Med El Combi 40+), d'une part, et modifié (surface cannelée), d'autre part. Résultats et conclusion: Une force dépassant les réalités physiologiques a été nécessaire pour retirer le câble-électrode gainé dans les tissus cicatriciels simulés. Le câble avec la surface cannelée s'avérait encore plus résistant: il déchirait même lorsqu'on a essayé de le retirer. Ceci vient donc conforter la confiance que nous avons dans la fixation biologique, c'est-à-dire dans l'ancrage de l'électrode dans les tissus cicatriciels. Une confiance qui est d'ailleurs confirmée par les expériences que nous avons pu faire dans notre clinique. Ainsi, en 8 ans, sur 80 opérations, au cours desquelles le câble de l'implant a été fixé en étant simplement placé dans de la fibrine, dans le cadre d'une tympanotomie postérieure, aucun déplacement de l'électrode n'a été constaté. Par conséquent, il ne s'avère pas nécessaire d'avoir recours à une fixation artificielle ou à une technique opératoire particulière pour assurer le bon maintien de l'électrode.

\footnotetext{
K.-B. Hüttenbrink, MD

Department of Oto-Rhino-Laryngology, Technical University Dresden

Fetscherstrasse 74

D-01307 Dresden (Germany)

Tel. +49 351458 4420, Fax +49 351458 4320, E-Mail huettenb@rcs.urz.tu-dresden.de
}
KARGER
Fax +41613061234 www.karger.com
() 2001 S. Karger AG, Basel
$1014-8221 / 00 / 0105-0213 \$ 17.50 / 0$
Accessible online at: www.karger.com/journals/orn 


\section{Introduction}

The tonotopic stimulation of cochlea implants requires a stable position of the electrodes inside the cochlea. An extraction of the cable, caused by a contraction of fibrous tissue, which surrounds the cable in the mastoid cavity, or the drag due to skull growth in small children, alters the coordination of the electrodes to their specific population of neurones in the spiral ganglion. This might jeopardize the hearing result.

This challenge has been recognized since the beginning of cochlea implant surgery. Efforts to control the dislocation have concentrated on anchoring the electrode cable near the cochlea $[1,2]$. Even in the expanding pneumatization in the maturating mastoid of the child, there is little change in the distance between the tip of the incus and the round window [3]. This made the posterior ear canal wall the preferred fixation point of the electrode cable, using ionomeric cement, dacron or platinum-wire tiedowns, or titanium clips [4-7]. Yet, the implantation of these foreign materials, especially the widely used cement, which has recently been withdrawn from the market, has met increasing criticism following the experience of revision surgery. In one of our reimplantations, 6 months after implantation, we found a definite foreign body reaction with bone resorption and bone remodelling near the dacron-mesh tie-down, which had been considered as well tolerated so far [8]. Even cholesteatoma development has been reported [9]. This revision surgery, on the other hand, confirmed the vast experience from tympanoplasty surgery that the silicon cover of the cochlea implant is accepted without any foreign body reaction. The implant is embedded in a new bone formation and connective tissue.

\section{Technique}

Due to our confidence in this biologic fixation, we have, for several years now, discharged all of the electrode cable's additional artificial anchoring materials, resulting in a simplification of the surgical manipulations. After the fixation of the receiver-stimulator by a nonresorbable suture to the skull and the insertion of the electrode cable into the cochlea, the cochleotomy is packed with fascia. The cable, which passes through the lower corner of the posterior tympanotomy is covered with fascia and fibrin glue (fig. 1). The superior portion of the tympanotomy remains open for the final optical control of the stapedius reflex.

The formation of connective tissue in the following weeks encases the electrode cable in a stable sheath. This biologic fixation has prevented a dislocation of the cable in more than 80 cases in the last 8 years in our Nucleus and Med El device implantations.

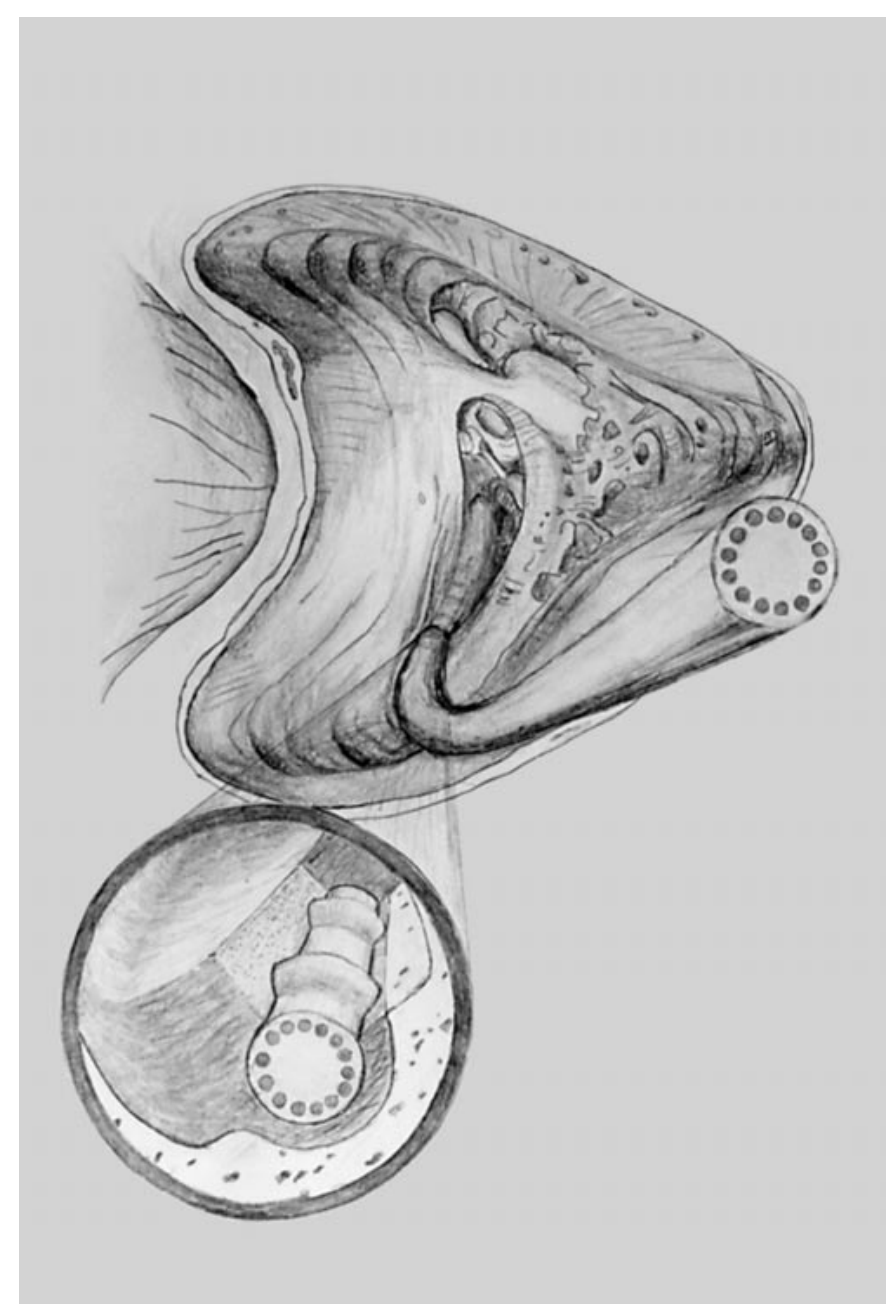

Fig. 1. The electrode cable is positioned in the groove of the lower end of the posterior tympanotomy and is securely anchored in a sheath of connective tissue after the cicatrization.

\section{Experiments}

In order to measure the anchoring forces of this connective tissue sheath in the posterior tympanotomy and to increase the stability of this biologic fixation, we performed experiments in fresh temporal bones with regular and modified electrode cables. The substantial frictional resistance between the silicone-coated cable and the connective tissue sheath can be increased by a modification of the cable's design. Hence, the manufacturer Med El (Innsbruck, Austria) provided us with a conventional smooth and with a profiled cable for these experiments (fig. 2). The idea for this design evolved from the experience of a revision surgery with a Med El device: The silicone globule, which characterizes the electrode cable of this producer as a marker for the presumptive cochleotomy position, was coated by a solid connective tissue sheath, which anchored the cable in the cochlea securely and resisted the tugs of extraction. The tissue had to be cut prior to a successful extraction of the cable out of the cochlea.

The simulation of this cicatrized connective tissue sheath posed a methodological problem for the experiments. Pure fibrin glue is too soft and will not hold the cable until its cicatrization and transformation into collagen tissue. A simple household adhesive, as it is used for bonding paper or wood (UHU-Alleskleber ${ }^{\circledR}$ ), proved to be ideal 
Fig. 2. Profiled electrode cable with multiple fixation rings for an increased resistance in its connective tissue sheath against extraction forces, as used for the temporal bone experiments.

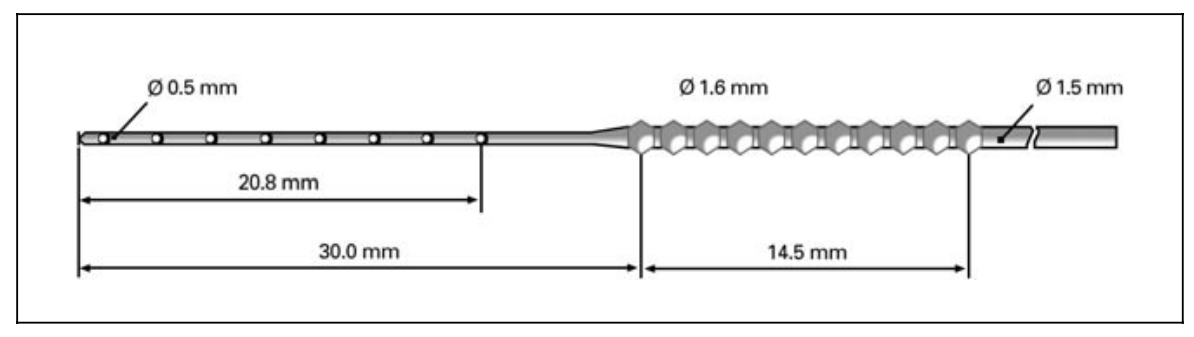

Fig. 3. Forces required for extraction of a conventional smooth surface electrode cable and a profiled electrode cable out of their bony groove after embedding in glue for $24 \mathrm{~h}$ at $4{ }^{\circ} \mathrm{C}$. The smooth cable glides at a force of $2.5 \mathrm{~N}$ (corresponding to a load of approx. $250 \mathrm{~g}$ ) out of the glue/bone sheath. A profiled cable resists much higher forces; in one of our experiments, the cable even ruptured.

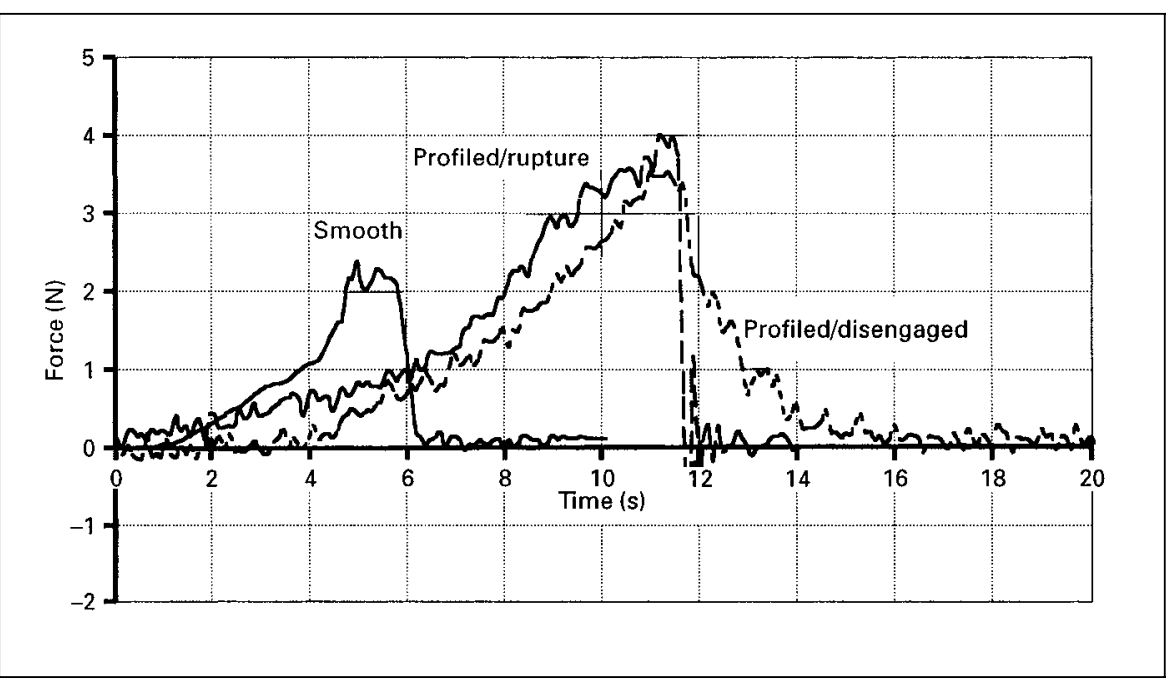

for our purposes after several trials. This glue develops a tough, rubber-like consistency after air exposure and 24-hour storage at $4{ }^{\circ} \mathrm{C}$, mimicking the stability of stringy, cicatrized connective tissue. The experimental determination of its elasticity modulus showed a value of $0.069 \mathrm{MP}$, which is still inferior to a strip of temporalis fascia (1.75 MP). Hence, using the glue to anchor the cable in the experimental set-up was even less stable than a sheath of cicatrized connective tissue with its collagen fibres in vivo. The glue did not adhere chemically to the silicone; silicone needs a specific silicone glue for bonding purposes.

In the first extraction experiments, we performed a deep cochlear insertion with a conventional electrode cable, and we positioned and glued the silicon cable in a posterior tympanotomy of a fresh temporal bone. The bending of the cable between tympanotomy and cochleostomy, however, altered the force vector of the drag, which resulted in an additional, delusive frictional component. We therefore drilled a groove $1 \mathrm{~cm}$ long and $1-2 \mathrm{~mm}$ deep into the plane of the squama ossis temporalis of the fresh temporal bone and anchored the cable with a drop of the UHU glue into the groove. Measurements started after $24 \mathrm{~h}$ storage of $4{ }^{\circ} \mathrm{C}$. Using a foil strain gauge technique and a micromanipulator with an accuracy of $0.1 \mathrm{mN}$ for methodical details of this technique see Hüttenbrink [10], we determined the axial force that was needed for pulling the cables with either smooth or profiled design out of their anchorage.

\section{Results}

The profiled electrode cable is anchored much more securely into the bony groove by the glue sheath than the conventional, smooth cable, as demonstrated in figure 3.
The drag during one extraction trial even resulted in the rupture of the cable. But the smooth surface of a conventional electrode cable is also anchored securely, since a load exceeding $200 \mathrm{~g}(2 \mathrm{~N})$ is needed for pulling it out of is anchorage.

\section{Conclusions}

These experimental results, as well as our clinical experiences, show that a biologic fixation due to a connective tissue sheath in the posterior tympanotomy guarantees a stable anchoring of the electrode cable of a cochlea implant, thus preventing cable extraction out of the cochlea. An additional fixation with foreign materials is not required and might even induce further risks, such as foreign body reaction, cholesteatoma development or damaging the delicate electrode cable with sharp-edged clips. Additional surgical manipulations, like the split-bridge technique [1], also appear unnecessary and not without risk, as demonstrated in a recent case report of a dislodged electrode cable [Streitberger Ch: case report on the 5th international implant workshop, Würzburg, Germany, June/July 1999]. The cable had been pushed into the epitympanon through the incus bridge, gliding alongside the incus body due to the spring-like elasticity of the electrode coil in the mastoid. The fragility of the structures at the 
incus bridge emphasizes the advantage of the simple but secure anchoring of the electrode cable in the solid bone of the lower portion of the posterior tympanotomy.

The producers of cochlea implant devices can improve the attachment of the cable by designing their electrode cable with a profiled surface on the first $2 \mathrm{~cm}$ outside the cochlea. This design would guarantee an optimal biologic fastening in the posterior tympanotomy, due to the encasing in the scar tissue even in cases with an incomplete insertion of the cable, like in cases of cochlear fibrosis.
The experience with revision cases has shown that reimplantation poses no problems. A splitting of the connective tissue sheath with a sickle knife frees the cable, allowing it to be pulled out of the cochlea easily. No additional risk to the facial nerve is created, as no supplementary drilling in the posterior tympanotomy is needed. The bony canal of the nerve remains intact. Even in revision cases, the splitting of the connective tissue sheath is performed on the lateral surface of the cable, on the opposite side of the facial nerve position.

\section{References}

1 Balkany Th, Telischi F: Fixation of the electrode cable during cochlea implantation: The Split Bridge Technique. Laryngoscope 1995; 105:217-218.

2 Lehnhardt E: Intracochleäre Plazierung der Cochlea-Implant-Elektroden in soft surgery technique. HNO 1993;41:356-359.

3 Dahm MC, Shepherd RK, Clark GM: The postnatal growth of the temporal bone and its implications for cochlea implantation in children. Acta Otolaryngol 1993;(suppl 505):4-39.
4 Müller J, Geyer G, Helms J: Ionomerzement in der Cochlea-Implant-Chirurgie. Laryngorhinootologie 1993;72:36-38.

5 Cohen NL, Kuzma J: Titanium Clip for cochlear implant electrode fixation. Ann Otol 1995; (suppl 166):402-403.

6 Kempf HG, Issing PR, Lenarz T: IonomerZement in der Cochlear-Implant-Chirurgie Anwendung und Langzeitergebnisse. Laryngorhinootologie 1996;75:388-391.

7 Müller J, Schön F, Helms J: Sichere Fixierung von Cochlear-Implant-Elektrodenträgern bei Kindern und Erwachsenen - Erste Erfahrungen mit einem neuen Titan-Clip. Laryngorhinootologie 1998;77:238-240.
8 Ketchum LD: Twenty-five-year follow-up evaluation of an active silicone/Dacron tendon interposition prosthesis: A case report. J Hand Surg 2000;25:731-733.

9 Kempf HG, Tempel S, Johann K, Lenarz T: Komplikationen der Cochlear Implant-Chirurgie bei Kindern und Erwachsenen. Laryngorhinootologie 1999;78:529-537.

10 Hüttenbrink KB: Die Bewegung der Gehörknöchelchen durch die Mittelohrmuskelkontraktion. Laryngorhinootologie 1989;68:614621. 